\title{
Musrizal Muin • Kunio Tsunoda \\ Biological performance of wood-based composites treated with a formulation of 3-iodo-2-propynyl butylcarbamate and silafluofen using supercritical carbon dioxide
}

\begin{abstract}
Wood-based composites (medium density fiberboard, hardwood plywood, softwood plywood, particleboard, and oriented strand board) treated with a mixture formulation of 3-iodo-2-propynyl butylcarbamate (IPBC) and silafluofen using supercritical carbon dioxide as a carrier solvent were evaluated for their resistance to biological attack in a laboratory study. The formulation was prepared by mixing $10 \mathrm{~g}$ of IPBC and $1 \mathrm{~g}$ of silafluofen in ethanol solution $(20 \mathrm{ml})$. Treatments were conducted at $35^{\circ} \mathrm{C} / 7.85 \mathrm{MPa}, 35^{\circ} \mathrm{C} / 9.81 \mathrm{MPa}$, and $55^{\circ} \mathrm{C} / 11.77 \mathrm{MPa}$ with the direct introduction of $20 \mathrm{ml}$ of the formulation into the treatment vessel with a capacity of ca. $2000 \mathrm{ml}$ at a rate of $2 \mathrm{ml} / \mathrm{min}$. Laboratory tests indicated that the treatment conditions used significantly enhanced the resistance of the treated wood-based composites against fungal and termite attacks. Because no significant difference in efficacy against both biodegrading agents was noticed regardless of the treatment conditions, the treatment at $35^{\circ} \mathrm{C} / 7.85 \mathrm{MPa}$ was thought to be the most economical in terms of energy consumption and performance of treated materials. However, the amount of biocides in a formulation must be carefully selected in accordance with the required treatment condition to ensure satisfactory performance of the treated wood-based composites against any biological agent.
\end{abstract}

Key words Supercritical carbon dioxide - Biological efficacy · Wood-based composite · 3-Iodo-2-propynyl butylcarbamate $($ IPBC) $\cdot$ Silafluofen

M. Muin $\cdot$ K. Tsunoda

Research Institute for Sustainable Humanosphere, Kyoto University, Kyoto, Japan

M. Muin $(\square)$

Forestry Department, Faculty of Agriculture and Forestry, Research Institute for Sustainable Humanosphere, Makassar 90245, Indonesia Tel. +62-411-585917; Fax +62-411-585917

e-mail: musrizal@yahoo.com

\section{Introduction}

The importance of various wood-based composites as building or structural materials has increased in recent times with an inevitable increase in the supply of small logs. On the other hand, there are many reports of fungal and termite attacks associated with the use of wood-based composites. ${ }^{1-3}$ Therefore, protection of the wood-based composite from both fungal and termite attacks should be considered together if they are used under conditions conducive to biological degradation.

Although current methods for the preservative treatment of wood-based composites such as chemical treatment of associated wood elements, glue-line treatment, or chemical treatment after manufacturing definitely contribute to the enhanced resistance of the wood-based composites against biological degradation, they unfortunately have some unfavorable side effects. ${ }^{4-7}$ In contrast, the application of supercritical carbon dioxide $\left(\mathrm{SC}-\mathrm{CO}_{2}\right)$ as a carrier solvent of biocide has been recently proved to be feasible for the preservative treatment of wood-based composites. ${ }^{8-11}$

Our previous studies demonstrated that $\mathrm{SC}-\mathrm{CO}_{2}$ treatments under conditions slightly above the critical point $\left(30.84^{\circ} \mathrm{C} / 7.40 \mathrm{MPa}\right)$ were suitable for the impregnation of wood-based composites with a fungicide, 3-iodo-2-propynyl butylcarbamate (IPBC), or an insecticide, silafluofen. ${ }^{10,11}$ However, the amount of biocide incorporated into the treatment vessel naturally plays an important role in achieving a sufficient retention for protecting the treated materials against both major degrading agents. The incorporation of $4 \mathrm{~g}$ IPBC in $20 \mathrm{ml}$ ethanol for the single $\mathrm{SC}-\mathrm{CO}_{2} \mathrm{im}-$ pregnation at the treatment temperatures of $35^{\circ}-55^{\circ} \mathrm{C}$ and pressures of $7.85-11.77 \mathrm{MPa}$ did not produce sufficient protection of the treated wood-based composites against decay fungi. ${ }^{10}$ Correspondingly, the incorporation of the same concentration of silafluofen under the same treatment conditions could completely prevent termite attack of any treated wood-based composites. ${ }^{11}$ These previous results suggest the necessity to introduce more IPBC and less silafluofen into the treatment vessel. 
Because a wood preservative by itself generally has no broad biocidal action against both decay fungi and termites, the current study was conducted to evaluate the efficacy of the preservative treatments with the IPBC-silafluofen mixture formulation. Concentrations of each biocide and treatment conditions were selected on the basis of the previous results, and the mixing ratio followed the commercial products for superficial treatment. Efficacy of each biocide was also determined with sapwood blocks of sugi (Cryptomeria japonica D. Don) to facilitate discussions of the results with $\mathrm{SC}-\mathrm{CO}_{2}$-treated wood-based composites.

\section{Materials and methods}

\section{Wood-based composites}

Specimens $(210 \times 30 \mathrm{~mm} \times$ thickness $)$ of commercial structural-use medium density fiberboard (MDF), hardwood plywood, softwood plywood, particleboard, and oriented strand board (OSB) were prepared and used for treatment. Some physical properties such as density and thickness of the wood-based composites are described in our previous publication. ${ }^{9}$ The specimens were double coated with epoxy resin on each cut end to simulate the penetration of SC- $\mathrm{CO}_{2}$ through surface areas of practicallysized products. All specimens were conditioned at $60^{\circ} \mathrm{C}$ for $72 \mathrm{~h}$ prior to $\mathrm{SC}-\mathrm{CO}_{2}$ treatment.

\section{Biocides}

Preservative stock solution was prepared by mixing the fungicide IPBC [99.1\% a.i. (Arch Chemicals, Cheshire, CT, USA) and the termiticide silafluofen [ $94.2 \%$ a.i. (Hoechst, Germany)] with the ratio of 10:1 [\% (w/v) a.i., 10g IPBC + $1 \mathrm{~g}$ silafuofen] in $20 \mathrm{ml}$ of ethanol [ $99.5 \%$ a.i. (Nacalai Tesque, Kyoto, Japan)]. The IPBC-silafluofen mixture formulation had an identical ratio of each constituent in the commercial formulation used for superficial treatment.

\section{Treatment}

Treatments with the preservative mixture formulation using SC- $\mathrm{CO}_{2}[99.5 \%$ [Kyoto Teisan, Kyoto, Japan)] as a carrier solvent were conducted at $35^{\circ} \mathrm{C} / 7.85 \mathrm{MPa}, 35^{\circ} \mathrm{C} / 9.81 \mathrm{MPa}$, and $55^{\circ} / 11.77 \mathrm{MPa}$. These treatment conditions were selected accordance with those producing promising results with either IPBC or silafluofen. ${ }^{10,11}$

Two specimens of each wood-based composite were placed in the treatment vessel for each run. The treatment vessel was immersed in a temperature-controlled water bath and preheated to the desired temperature. Liquefied $\mathrm{CO}_{2}$ was then introduced into the treatment vessel until the pressure in the vessel reached an equal level of the $\mathrm{CO}_{2}$ source. The pressure was raised to the target level by introducing liquefied $\mathrm{CO}_{2}$ into the treatment vessel with a double pressure pump at a rate of $9 \mathrm{ml} / \mathrm{min}$. After the pressure reached the critical level of $\mathrm{CO}_{2}$, the $20 \mathrm{ml}$ of preservative solution was immediately introduced into the treatment vessel using another double pump at a rate of $2 \mathrm{ml} / \mathrm{min}$. The treatment vessel was maintained under the test conditions for $30 \mathrm{~min}$ to allow preservatives and $\mathrm{SC}-\mathrm{CO}_{2}$ to evenly circulate inside the vessel without any additional force. At the end of treatment, pressure was released to the ambient atmospheric pressure and the treated materials were recovered for the subsequent tests. Treatments were conducted three times at each condition to produce six replicates of each wood-based composite.

Biological tests of untreated and treated wood-based composites

Decay and termite tests were conducted according to JIS K $1571(1998)^{12}$ and JWPA standard JWPS-TW-P.1 (2001), respectively. ${ }^{13}$ The sampling of test blocks from the original specimens was done as shown in Fig. 1, producing 36 specimens $(28 \times 20 \mathrm{~mm} \times$ thickness $)$ for the decay tests and another 12 specimens $(20 \times 13 \mathrm{~mm} \times$ thickness $)$ for the termite tests. Same-size specimens of untreated materials were also prepared as controls. The untreated and treated specimens were oven-dried at $60^{\circ} \mathrm{C}$ for $48 \mathrm{~h}$ and their initial weights were recorded.

Specimens for the decay tests were then sterilized with gaseous ethylene oxide. Three wood blocks were exposed to a monoculture of either the white-rot fungus Trametes versicolor (L.: Fr.) Pilat (fungal accession number of the Forestry and Forest Products Research Institute, Tsukuba, Japan: FFPRI 1030) or the brown-rot fungus Fomitopsis palustris (Berk. et Curt.) Gilbn. and Ryv. (FFPRI 0507) in a glass jar at $26^{\circ} \pm 2^{\circ} \mathrm{C}$ for 12 weeks. Three decay jars were used to test nine replicates of each treated material group against the two decay fungi. The remaining 18 blocks were also exposed to the same test units without active decay fungi to correct for weight changes associated with unforeseen causes other than decay fungi. Percent mass loss was calculated from the difference in oven-dried weights of each block before and after the decay test.

Of the specimens for termite tests, five test blocks were randomly selected and placed at the center of the plaster bottom of cylindrical test containers $(8 \mathrm{~cm}$ in diameter; $6 \mathrm{~cm}$ in height). A total of 150 workers and 15 soldiers of Coptotermes formosanus Shiraki were introduced into each test container. Containers of the same test units with the other five randomly selected blocks were also prepared without termites to correct for weight changes associated with unforeseen causes other than termite attacks. The as-

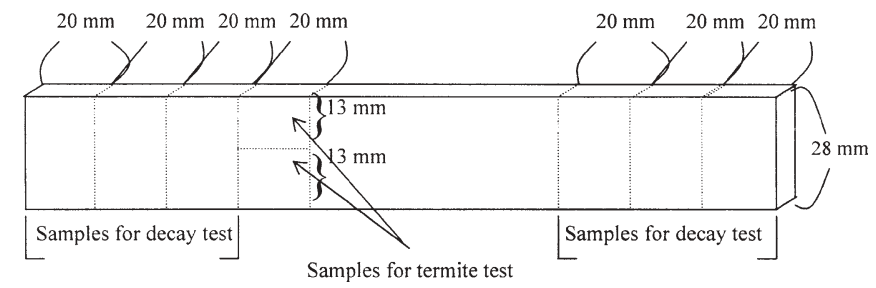

Fig. 1. Sampling of wood specimens for decay and termite tests of treated wood-based composites 
sembled containers were set on a damp cotton pad and kept at $28^{\circ} \pm 2^{\circ} \mathrm{C}$ and over $80 \%$ relative humidity in the dark for 3 weeks. Percent mass loss of each test block was calculated from the difference in oven-dried weight before and after the termite test. Termite mortality and consumption rates (the amount of wood-based composite eaten divided by the total days of worker termites during the exposure period) were also calculated.

All results of the biological assay of the untreated controls and treated materials were compared by Tukey's test with $P<0.01$ considered statistically significant.

Evaluation of biocide efficacy using sugi sapwood specimens

Additionally, the efficacy of each biocide used was examined with sugi sapwood blocks $[20(\mathrm{R}) \times 20(\mathrm{~T}) \times 10(\mathrm{~L})$ $\mathrm{mm}$ ] after vacuum-soak impregnation with biocidal solutions. Treatment solutions were prepared with ethanol to achieve the target retentions of $0.3,0.6$, and $0.9 \mathrm{~kg} / \mathrm{m}^{3}$ for IPBC and $0.025,0.050$, and $0.100 \mathrm{~kg} / \mathrm{m}^{3}$ for silafluofen. Theoretical retention of each block was calculated from treatment concentration, solution uptake, and volume of the specimen to determine the mean value of the same treatment group. The decay and termite resistance of untreated and treated sugi blocks were then tested according to the above-mentioned procedures.

\section{Results and discussion}

Percent mass losses of untreated and IPBC-silafluofen/SC$\mathrm{CO}_{2}$-treated wood-based composites against decay fungi and termite attack are presented in Tables 1 and 2, respectively. It is clearly shown that each type of wood-based composite had a different natural durability against both major biodegrading agents and the IPBC-silafluofen treatment significantly enhanced the resistance of the treated materials to biological degradation. The untreated MDF seemed to resist against fungal and termite attacks as shown by small mass losses and large termite mortality. One possible reason is the origin of associated compounds in the manufacturing process of the wood-based composite that may consist of a high percentage of naturally resistant heartwood. ${ }^{2}$ Because the mass loss figures of untreated MDF, hardwood plywood, and particleboard against Fomitopsis palustris and that of untreated particleboard against. Trametes versicolor were small, they were discarded for statistical comparison (Table 1). Statistical comparison for the mass loss of MDF by Coptotermes formosanus was not considered due to the same reason (Table 2).

Table 1 shows that most of the treatments suppressed both decay fungi to a satisfactory mean mass loss of less than $3 \%$. All treatment conditions equally enhanced the decay resistance of MDF and softwood plywood. The treatment of hardwood plywood and OSB at $35^{\circ} \mathrm{C} / 7.85 \mathrm{MPa}$ sustained mean mass loss slightly higher than $3 \%$ against $T$. versicolor, although they were not significantly different to the treatment at $55^{\circ} \mathrm{C} / 11.77 \mathrm{MPa}$, which resulted in a satisfactory 
Table 2. Percentage mass loss of wood-based composites treated with IPBC-silafluofen mixture formulations using $\mathrm{SC}-\mathrm{CO}_{2}$ impregnation after exposure to Coptotermes formosanus

\begin{tabular}{|c|c|c|c|c|c|}
\hline $\begin{array}{l}\text { Treatment } \\
\text { conditions }\end{array}$ & $\begin{array}{l}\text { Medium density } \\
\text { fiberboard }^{\mathrm{a}}\end{array}$ & $\begin{array}{l}\text { Hardwood } \\
\text { plywood }\end{array}$ & $\begin{array}{l}\text { Softwood } \\
\text { plywood }\end{array}$ & Particleboard & $\begin{array}{l}\text { Oriented strand } \\
\text { board }\end{array}$ \\
\hline Untreated control & $3.70 \pm 0.92$ & $10.97 \pm 1.31$ & $15.05 \pm 3.29$ & $9.21 \pm 3.23$ & $15.93 \pm 2.64$ \\
\hline $35^{\circ} \mathrm{C} / 7.85 \mathrm{MPa}$ & $2.52 \pm 0.84$ & $5.19 \pm 2.26^{*}$ & $6.91 \pm 2.69 *$ & $4.10 \pm 0.87 *$ & $3.87 \pm 1.32 *$ \\
\hline $35^{\circ} \mathrm{C} / 9.81 \mathrm{MPa}$ & $2.18 \pm 0.61$ & $3.74 \pm 1.19 *$ & $4.70 \pm 2.34^{*}$ & $3.04 \pm 1.01 *$ & $3.70 \pm 1.98^{*}$ \\
\hline $55^{\circ} \mathrm{C} / 11.77 \mathrm{MPa}$ & $2.39 \pm 0.70$ & $4.06 \pm 2.58 *$ & $5.74 \pm 1.64 *$ & $2.79 \pm 1.77 *$ & $5.36 \pm 1.12 *$ \\
\hline
\end{tabular}

Results given as mean values and standard deviations of five replicates

Values in a column marked with an asterisk are significantly different from the control by Tukey's test $(P<0.01)$

${ }^{a}$ Statistical comparison of treatment efficacies was discarded because of the small mass loss of untreated materials

Table 3. Percentage mass loss of sugi sapwood blocks impregnated with IPBC and silafluofen in ethanol solution

\begin{tabular}{|c|c|c|c|c|c|}
\hline \multirow[t]{2}{*}{ Biocides } & \multirow{2}{*}{$\begin{array}{l}\text { Target } \\
\text { retention }\left(\mathrm{kg} / \mathrm{m}^{3}\right)\end{array}$} & \multirow{2}{*}{$\begin{array}{l}\text { Retention } \\
\text { determined by } \\
\text { solution uptake }\left(\mathrm{kg} / \mathrm{m}^{3}\right)\end{array}$} & \multicolumn{3}{|l|}{ Mass loss (\%) } \\
\hline & & & $\begin{array}{l}\text { Trametes } \\
\text { versicolor }\end{array}$ & $\begin{array}{l}\text { Fomitopsis } \\
\text { palustris }\end{array}$ & $\begin{array}{l}\text { Coptotermes } \\
\text { formosanus }\end{array}$ \\
\hline \multirow{4}{*}{ IPBC } & 0 & 0 & $23.42 \pm 3.65$ & $24.04 \pm 7.95$ & - \\
\hline & 0.30 & 0.30 & $27.94 \pm 4.86$ & $0.00 \pm 0.00$ & - \\
\hline & 0.60 & 0.59 & $0.00 \pm 0.00$ & $0.00 \pm 0.00$ & - \\
\hline & 0.90 & 0.90 & $0.00 \pm 0.00$ & $0.00 \pm 0.00$ & - \\
\hline \multirow[t]{4}{*}{ Silafluofen } & 0 & 0 & - & - & $24.74 \pm 3.58$ \\
\hline & 0.025 & 0.025 & - & - & $0.00 \pm 0.00$ \\
\hline & 0.050 & 0.050 & - & - & $0.00 \pm 0.00$ \\
\hline & 0.100 & 0.099 & - & - & $0.00 \pm 0.00$ \\
\hline
\end{tabular}

performance. Treatment at $35^{\circ} \mathrm{C} / 9.81 \mathrm{MPa}$ seemed to be less effective, especially for OSB against decay fungi. This condition was probably related to the permeability of the treated material and the density of $\mathrm{CO}_{2}$ introduced for treatment. Based on the quantity of $\mathrm{CO}_{2}$ introduced into the treatment vessel, the $\mathrm{CO}_{2}$ density was approximately $420.20,628.18$, and $499.92 \mathrm{~kg} / \mathrm{m}^{3}$ at $35^{\circ} \mathrm{C} / 7.85 \mathrm{MPa}, 35^{\circ} \mathrm{C} / 9.81 \mathrm{MPa}$, and $55^{\circ} \mathrm{C} / 11.77 \mathrm{MPa}$, respectively. The increase of $\mathrm{CO}_{2}$ density at $35^{\circ} \mathrm{C} / 9.81 \mathrm{MPa}$ seems to adversely affect the deposition of IPBC within the treated OSB, resulting in less resistance to decay fungi. Because board permeability is mainly determined by the pores between the associated wood particles and not by the particles themselves, the polygonal pores formed by associated strands in OSB will become short due to the compression of the strands in manufacturing process and thus show a reduced resistance to flow. ${ }^{14}$ This factor may contribute to the difficulty of biocide movement or distribution when the treatment is conducted at low concentrations of the incorporated biocide (higher density of $\mathrm{SC}-\mathrm{CO}_{2}$ ). However, investigations on the behavior of the chemical during the treatment process might be useful for a better understanding of this phenomenon.

Table 2 demonstrates the efficacy of IPBC-silafluofen/ $\mathrm{SC}-\mathrm{CO}_{2}$ treatments against $C$. formosanus. All current treatment conditions provided all wood-based composites with an equally high termite resistance as a whole. This result was in agreement with the findings on termite mortality (Fig. 2) and the consumption rates of wood-based composites (Fig. 3). On the basis of that there was no discrepancy in efficacy among the current conditions, treatment at $35^{\circ} \mathrm{C} / 7.85 \mathrm{MPa}$ could be the most cost-efficient

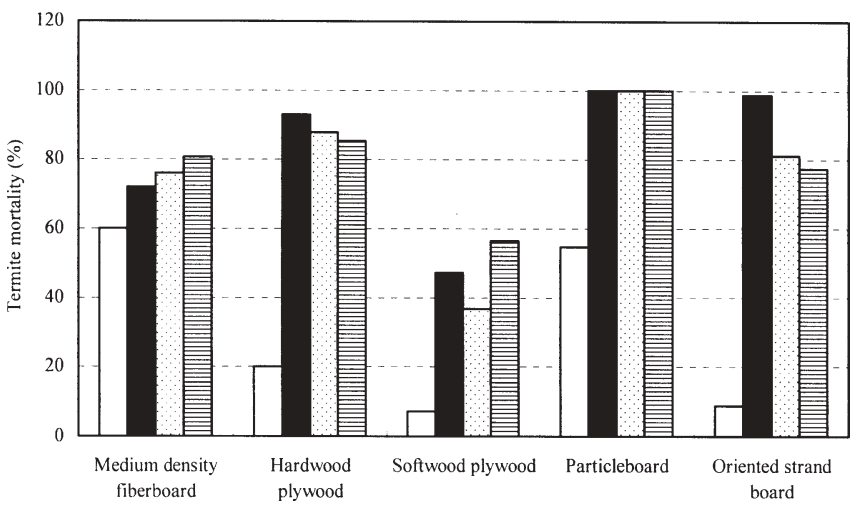

Fig. 2. Mortality of Coptotermes formosanus exposed to wood-based composites treated with 3-iodo-2-propynyl butylcarbamate (IPBC)silafluofen mixture formulation using supercritical $\mathrm{CO}_{2}\left(\mathrm{SC}-\mathrm{CO}_{2}\right)$ impregnation at various treatment conditions. Open bars, untreated controls; filled bars, $35^{\circ} \mathrm{C} / 7.85 \mathrm{MPa}$; dotted bars, $35^{\circ} \mathrm{C} / 9.81 \mathrm{MPa}$; horizontal-lined bars, $55^{\circ} \mathrm{C} / 11.77 \mathrm{MPa}$

condition. The feasibility of the SC- $\mathrm{CO}_{2}$ application is associated with the fact that the treatment seems to transport a sufficient amount of biocides into the wood-based composites to protect them from biological degradation. In addition, although current conventional methods for impregnating wood-based composites with preservative solutions are relatively easier, they create permanent, unfavorable swelling and decrease the internal bond strength, ${ }^{7}$ which were not found in the $\mathrm{SC}-\mathrm{CO}_{2}$ treatment.

The efficacy of the current $\mathrm{SC}-\mathrm{CO}_{2}$ treatment conditions with IPBC-silafluofen mixture formulation can be compared to the previous results on the efficacy of each of the 


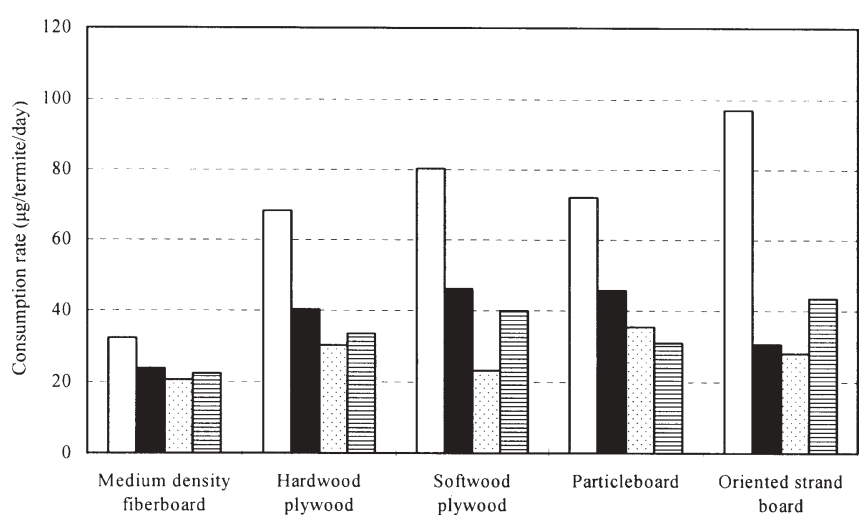

Fig. 3. Consumption rate of Coptotermes formosanus of wood-based composites treated with IPBC-silafluofen mixture formulation using $\mathrm{SC}-\mathrm{CO}_{2}$ impregnation at various treatment conditions Open bars, untreated controls; filled bars, $35^{\circ} \mathrm{C} / 7.85 \mathrm{MPa}$; dotted bars, $35^{\circ} \mathrm{C} / 9.81 \mathrm{MPa}$; horizontal-lined bars, $55^{\circ} \mathrm{C} / 11.77 \mathrm{MPa}$

biocides in terms of relative efficiency (RE) against biological degradation calculated as [(mean percent mass loss of the untreated specimens - mean percent mass loss of the treated specimens) / (mean percent mass loss of the untreated specimen) $] \times 100$. The $\mathrm{RE}$ of treatment at $35^{\circ} \mathrm{C} / 7.85 \mathrm{MPa}$ with $20 \%(\mathrm{w} / \mathrm{v}) \mathrm{IPBC}$ in ethanol changed from 63, 11, 16, and 21 for MDF, hardwood plywood, softwood plywood, and OSB, respectively, against T. versicolor ${ }^{10}$ to $67,86,61$, and 89 with $50 \%(\mathrm{w} / \mathrm{v})$ IPBC concentration in the current study. On the other hand, the $\mathrm{RE}$ of treatment at $35^{\circ} \mathrm{C} / 7.85 \mathrm{MPa}$ with $20 \%$ (w/v) silafluofen in ethanol changed from 100, 100, 94, and 81 for hardwood plywood, softwood plywood, particleboard, and OSB, respectively, against termite (C. formosanus) attack ${ }^{11}$ to $53,54,55,76$, respectively, with $5 \%$ (w/v) silafluofen in this study. These facts indicated that the higher concentration of biocides produced higher treatment efficacy. In addition, there was negligible decrease in efficacy by mixing two biocides as a formulation.

As presented in Table 3, the efficacy data of impregnated sugi sapwood blocks together with retentions show that IPBC performed well in protecting specimens from fungal attack at the retention level of $0.60 \mathrm{~kg} / \mathrm{m}^{3}$ and silafluofen showed excellent performance against termite attack even at the lowest retention rested in this study $\left(0.025 \mathrm{~kg} / \mathrm{m}^{3}\right)$. Although theoretical maximum retentions of IPBC and silafluofen in the wood-based composites, calculated in the same way as previously reported ${ }^{10}$ were much higher than the toxic value, some treatments still sustained slight attack with a mean mass loss of more than $3 \%$, particularly against termites. These results appear to suggest that only a small portion of the biocides introduced into the treatment vessel were taken up by the samples and suggest the necessity to add small amount of silafluofen to the mixture formulation to achieve satisfactory performance of wood-based composites. The low intake of the incorporated biocides by the treated wood-based composites under the treatment conditions employed also suggests the need to develop a closed $\mathrm{SC}-\mathrm{CO}_{2}$ treatment process that enables efficient recovery and reuse of carbon dioxide and active ingredients for economic and environmental benefits.

\section{Conclusions}

Treatment of wood-based composites with a mixture formulation of fungicide-termiticide such an IPBC-silafluofen using $\mathrm{SC}-\mathrm{CO}_{2}$ as a carrier solvent is capable of enhancing the resistance of the treated materials to decay and termite attack. The treatment could be conducted at $35^{\circ} \mathrm{C}$ and 7.85 MPa, the simplest and most energy-efficient conditions because they produced comparable performance to that of other treatment conditions in the investigation. The application of SC- $\mathrm{CO}_{2}$ did not seem to work well for the impregnation of a biocidal mixture formulation having an identical ratio to a commercial formulation commonly used for superficial treatment because of the imbalance in effectiveness against both decay fungi and termite attack. Therefore, the adjustment of the amount of biocides in a mixture formulation for SC- $\mathrm{CO}_{2}$ impregnation is needed to provide the treated wood-based composites with satisfactory protection against any biological agent.

\section{References}

1. Becker G (1972) Protection of wood particleboard against termites. Wood Sci Technol 6:239-248

2. Behr EA (1972) Decay and termite resistance of medium-density fiberboards made from wood residue. Forest Prod J 22:48-51

3. Schmidt H, Nehm AB (1972) Testing of particleboard on termite resistance. Holz Roh Werkst 30:175-177

4. Jeihooni A, Krahmer RL, Morrell JJ (1994) Properties and decay resistance of preservative-treated douglas-fir flakeboard. Wood Fiber Sci 26:178-184

5. Laks PE, Haataja BA, Palardy RD, Bianchini RJ (1988) Evaluation of adhesive for bonding borate-treated flakeboards. Forest Prod J 38:23-24

6. Boggio K, Gertjejansen RO (1982) Influence of ACA and CCA waterborne preservatives on the properties of aspen waferboard. Forest Prod J 32:22-26

7. Schmidt EL, Gertjejansen RO (1988) Trials of two powdered preservatives for phenol-formaldehyde-bonded and polymeric-isocyanate-bonded aspen structural composite board. Forest Prod J 38:19-21

8. Acda MN, Morrell JJ, Levien KL (1996) Decay resistance of composites following supercritical fluid impregnation with tebuconazole. Mater Organismen 30:293-300

9. Muin M, Adachi A, Inoue M, Yoshimura T, Tsunoda K (2003) Feasibility of supercritical carbon dioxide as a carrier solvent in the preservative treatment of wood-based composites. J Wood Sci 49:65-72

10. Muin M, Tsunoda K (2003) Preservative treatment of woodbased composites with 3-iodo-2-propynyl butylcarbamate using supercritical carbon dioxide impregnation. J Wood Sci 49:430-436

11. Muin M, Tsunoda K (2003) Termiticidal performance of woodbased composites treated with silafluofen using supercritical carbon dioxide. Holzforschung 57:585-592

12. JIS K 1571 (1998) Qualitative standards and testing methods of wood preservatives. Japanese Industrial Standard (JIS), Japanese Standards Association, Tokyo

13. JWPS-TW-P.1 (2001) Laboratory test method to evaluate effectiveness of termiticides for pressure treatment and performance requirements of the treated materials. Japan Wood Preserving Association

14. Bolton AJ, Humphrey PE (1994) The treatability of wood-based composite materials. Holzforschung 48 Suppl:95-100 